\title{
Palliative care and nursing in dissertations and theses in Portugal: a bibliometric study
}

\section{Cuidados paliativos e enfermagem nas dissertações e teses em Portugal: um estudo bibliométrico \\ Cuidados paliativos y enfermería en las tesis de maestría y doctorado en Portugal: un estudio bibliométrico}

Maria Amélia Leite Ferreira ${ }^{1,2}$, Alexandra Manuela Nogueira de Andrade Pereira ${ }^{1,2}$, José Carlos Amado Martins ${ }^{3,4}$, Maria do Céu Barbieri-Figueiredo ${ }^{1,5}$

How to cite this article:

Ferreira MAL, Pereira AMNA, Martins JCA, Barbieri-Figueiredo MC. Palliative care and nursing in dissertations and theses in Portugal: a bibliometric study. Rev Esc Enferm USP. 2016;50(2):313-319. DOI: http://dx.doi.org/10.1590/S0080-623420160000200019

${ }^{1}$ Instituto de Ciências Biomédicas Abel Salazar, Lousada, Porto, Portugal.

${ }^{2}$ Unidade de Cuidados à Comunidade de Lousada, Lousada, Porto, Portugal.

${ }^{3}$ Escola Superior de Enfermagem de Coimbra, Coimbra, Portugal.

${ }^{4}$ Universidade do Porto, Faculdade de Medicina, Porto, Portugal.

${ }^{5}$ Escola Superior de Enfermagem do Porto, Porto, Portugal.

\begin{abstract}
Objective: To identify the academic scientific production on palliative care in master dissertations and $\mathrm{PhD}$ theses carried out by nurses in Portugal. Method: A descriptive retrospective study of bibliometric type with search for the abstracts available in repositories of higher education institutions in the period 2000-2014. Results: Of the 1814 papers identified, 249 met the inclusion criteria (ten doctoral theses and 239 master dissertations). The most representative methodological approach was quantitative $(31.35 \%)$ and the most studied area was family/informal caregiver $(20.69 \%)$. The most studied target population were the students/health professionals (38.51\%). Conclusion: The academic scientific production in this area has been growing in spite of the need for continued investment in order to fill the identified gaps.
\end{abstract}

DESCRIPTORS

Palliative Care; Nursing; Bibliometrics; Portugal. 


\section{INTRODUCTION}

Palliative care is defined by the World Health Organization as an approach to improve the quality of life of patients and their families facing problems resultant from an incurable disease with limited prognosis, and/or a serious illness (life-threatening) through prevention and relief of suffering by means of the early identification, proper evaluation and rigorous treatment of physical problems such as pain, and psychosocial and spiritual problems $\mathrm{s}^{(1)}$.

Internationally, palliative care emerged in the 1960s as consequence of the hospice movement in the United Kingdom. In Portugal, palliative care is a relatively recent phenomenon, the result of some pioneering movements. The first inpatient unit arose in 1992 in a hospital in the center of the country. Four years later appeared the first community based unit near the capital ${ }^{(2)}$.

Only in 2004 appeared a clear government initiative for the dissemination of palliative care with publication of its national program ${ }^{(3)}$ and the later publication of a specific legislation.

Although still well below the estimated needs of Portugal ${ }^{(4)}$, in the National Palliative Care Directory currently there are 26 inpatient units, 31 in-hospital teams and 15 community teams ${ }^{(5)}$.

Following the international trend, the provision of palliative care in Portugal is developed in parallel with research, resulting in the widespread interest in palliative care, especially after the change of the millennium ${ }^{(6)}$.

Internationally, palliative care research has contributed to its dissemination and implementation, with a key role in the fulfillment of its principles, philosophy and goals ${ }^{(7-8)}$. In fact, research is closely related to the clinical development of palliative care ${ }^{(9)}$.

Research is often associated with training, particularly postgraduate education. This issue is of such importance that the opportunity deficits in education and training are often cited as barriers to the development of palliative care in Western Europe ${ }^{(10-11)}$.

In Portugal, the offer of training in this area has been increasing. After the creation of the first master course in palliative care in 2002 at the Universidade de Lisboa ${ }^{(2)}$, five other courses are currently available in different universities in the country (Universidade Católica, Universidade do Porto, Universidade de Coimbra, Instituto Politécnico de Viana do Castelo and Instituto Politécnico de Castelo Branco) ${ }^{(12)}$.

Although palliative care is an interdisciplinary approach $^{(13-15)}$, the importance of nurses in the team is undeniable. They are the first link between the team, and the patient and family ${ }^{(16-17)}$. Some authors claim that the philosophy of palliative care requires the contribution of many disciplines, and identifying the contribution of each of them is essential to enhance the interdisciplinary perspective and provide high quality care ${ }^{(18)}$.

In this sense, and although there is evidence of research in palliative care in Portugal ${ }^{(8,19)}$, a gap was found on the study of the production of theses and dissertations conducted by nurses in this area. Academic research is greatly important in the context of palliative care, since the external funding for research is residual ${ }^{(11)}$.

Given the importance of nursing in palliative care, we deemed necessary to know which themes the nurses have chosen as object of study within this context. The choice of postgraduate academic research to the detriment of research papers published in indexed journals is justified by the need to know the themes that interest the majority of nurses. Also because there is evidence that just a small part of the research in palliative care in Portugal is published ${ }^{(8)}$.

Thus, emerged the following questions: What is the academic scientific literature on palliative care produced by Portuguese nurses who have completed master's degrees and doctorates? Which main themes are the subject of study of nurses who completed master and doctoral programs on palliative care? and What are the types of studies and target population used by nurses who completed master and doctoral programs on palliative care?

Considering the questions that originated this study, the aims are to: Identify the academic scientific literature on palliative care of Portuguese nurses who completed master's degrees and doctorates; Describe the main themes that were the subject of study of nurses who completed master and doctoral programs on palliative care; Know the types of studies and target population used by nurses who completed master and doctoral programs on palliative care.

\section{METHOD}

This is a bibliometric, descriptive and retrospective study. It was carried out through documentary research, a method that allows an objective evaluation of the scientific production and is used in various fields of scientific knowledge. The technique of bibliometric research comprises reading, selecting and filing the topics of interest to the research in question in order to know the scientific contributions on a given subject ${ }^{(20-21)}$.

Bibliometric indicators use the scientific production results to answer questions about the impact of research in the scientific community. In nursing, these studies are used to identify the scientific production characteristics. This is a relevant technology because it highlights the patterns and trends of research in different areas and themes ${ }^{(22-23)}$.

The material for analysis was limited to master dissertations (MD) and $\mathrm{PhD}$ theses (DT), written by nurses and published in scientific repositories of various universities and polytechnic institutes in Portugal between 2000 and 2014. The period before the year 2000 was not analyzed for two reasons. On the one hand, there was increased availability of master and doctoral courses in Portugal from that year, resulting in a greater accessibility to them. On the other hand, since the search was in electronic repositories, the number of available studies before the year 2000 was residual. Therefore, despite the existence of some studies out of this period, their inclusion would not be significantly relevant to the present study results. 
This study was developed independently by two researchers through research in Portuguese repositories linked to the health sciences identified in the Ranking Web of Repositories between February 24 and March $2,2015^{(24)}$. The search terms used were 'palliative care' in the fields 'subject' or 'description' or 'keyword'. The identification of authors as nurses was conducted using the electronic register of the Ordem dos Enfermeiros.

For the identification of concepts, the theses and dissertations were analyzed through title and abstract. When there were differences in analysis, the decisions were taken jointly after discussion.

The ethical procedures were guaranteed through rigorous methodology compliance and respect for ethical principles that guide health research.

\section{RESULTS}

In the various universities and polytechnics in Portugal were identified 31 repositories and 1814 studies. Initially, 1565 were excluded, of which 164 did not correspond to doctoral theses nor to master dissertations, and six were repeated. After reading the abstract, we concluded that 1251 did not fit the theme and 144 were performed by health professionals who were not nurses.

Thus, were identified 249 academic studies conducted by nurses with the theme of palliative care. Of these, ten were doctoral theses (4.02\%) and 239 were master dissertations $(95.98 \%)$. The earliest work was conducted in 2000 and corresponds to a master dissertation. Although there was no scientific production in 2001 and 2002, over the last six years the production has been growing significantly, as shown in Table 1.

Table 1 - Distribution of scientific production by type and per year - Portugal, 2000-2014.

\begin{tabular}{|c|c|c|c|c|c|c|}
\hline \multirow{2}{*}{ Years } & \multicolumn{2}{|c|}{ Theses (PhD) } & \multicolumn{2}{|c|}{ Dissertations (masters) } & \multicolumn{2}{|c|}{ Total } \\
\hline & $\mathbf{N}$ & $\%$ & $\mathbf{N}$ & $\%$ & $\mathbf{N}$ & $\%$ \\
\hline 2000 & 0 & 0,00 & 1 & 0.40 & 1 & 0.40 \\
\hline 2003 & 0 & 0,00 & 1 & 0.40 & 1 & 0.40 \\
\hline 2004 & 0 & 0,00 & 2 & 0.80 & 2 & 0.80 \\
\hline 2005 & 1 & 0,40 & 0 & 0.00 & 1 & 0.40 \\
\hline 2006 & 0 & 0,00 & 1 & 0.40 & 1 & 0.40 \\
\hline 2007 & 0 & 0,00 & 6 & 2.41 & 6 & 2.41 \\
\hline 2008 & 0 & 0,00 & 6 & 2.41 & 6 & 2.41 \\
\hline 2009 & 0 & 0,00 & 16 & 6.43 & 16 & 6.43 \\
\hline 2010 & 3 & 1,21 & 21 & 8.43 & 24 & 9.64 \\
\hline 2011 & 1 & 0,40 & 35 & 14.06 & 36 & 14.46 \\
\hline 2012 & 1 & 0,40 & 54 & 21.69 & 55 & 22.09 \\
\hline 2013 & 1 & 0,40 & 50 & 20.08 & 51 & 20.48 \\
\hline 2014 & 3 & 1,21 & 46 & 18.47 & 49 & 19.68 \\
\hline Total & 10 & 4,02 & 239 & 95.98 & 249 & 100.00 \\
\hline
\end{tabular}

Regarding the educational institutions where the studies were conducted, 19 of the 31 repositories had studies that corresponded to the initially outlined inclusion criteria. In terms of scientific production, there was predominance of the repositories of the Universidade
Católica (21.29\%), the Universidade de Lisboa (18.47\%) and the Universidade do Porto (15.66\%) (Table 2). It was also found that $57.83 \%(n=144)$ of academic works were produced in specific master and doctorate degrees in palliative care.

Table 2 - Distribution of scientific production by repository and type ( $\mathrm{N}$ and \%) - Portugal, 2000-2014.

\begin{tabular}{|c|c|c|c|c|c|c|}
\hline \multirow{2}{*}{ Repository } & \multicolumn{2}{|c|}{ Theses (PhD) } & \multicolumn{2}{|c|}{ Dissertations (masters) } & \multicolumn{2}{|c|}{ Total } \\
\hline & $\mathbf{N}$ & $\%$ & $\mathbf{N}$ & $\%$ & $\mathbf{N}$ & $\%$ \\
\hline U. Católica & 3 & 30.00 & 50 & 20.92 & 53 & 21.29 \\
\hline U. Lisboa & 3 & 30.00 & 43 & 17.99 & 46 & 18.47 \\
\hline U. Porto & 1 & 10.00 & 38 & 15.90 & 39 & 15.66 \\
\hline IP Castelo Branco & 0 & 0.00 & 35 & 14.64 & 35 & 14.06 \\
\hline IP Viana do Castelo & 0 & 0.00 & 23 & 9.62 & 23 & 9.24 \\
\hline U. Aveiro & 2 & 2.00 & 9 & 3.77 & 11 & 4.42 \\
\hline
\end{tabular}


...continuation

\begin{tabular}{|c|c|c|c|c|c|c|}
\hline \multirow{2}{*}{ Repository } & \multicolumn{2}{|c|}{ Theses (PhD) } & \multicolumn{2}{|c|}{ Dissertations (masters) } & \multicolumn{2}{|c|}{ Total } \\
\hline & $\mathbf{N}$ & $\%$ & $\mathbf{N}$ & $\%$ & $\mathbf{N}$ & $\%$ \\
\hline IP Viseu & 0 & 0.00 & 10 & 4.18 & 10 & 4.02 \\
\hline IP Bragança & 0 & 0.00 & 5 & 2.09 & 5 & 2.01 \\
\hline U. Coimbra & 0 & 0.00 & 5 & 2.09 & 5 & 2.01 \\
\hline RCAAP & 0 & 0.00 & 4 & 1.67 & 4 & 1.61 \\
\hline U. Algarve & 0 & 0.00 & 4 & 1.67 & 4 & 1.61 \\
\hline ESENFC & 0 & 0.00 & 3 & 1.26 & 3 & 1.20 \\
\hline U. Aberta & 1 & 1.00 & 2 & 0.84 & 3 & 1.20 \\
\hline U. Açores & 0 & 0.00 & 3 & 1.26 & 3 & 1.20 \\
\hline IP Porto & 0 & 0.00 & 1 & 0.42 & 1 & 0.40 \\
\hline ISCTE-IUL & 0 & 0.00 & 1 & 0.42 & 1 & 0.40 \\
\hline U. Beira interior & 0 & 0.00 & 1 & 0.42 & 1 & 0.40 \\
\hline U. Fernando Pessoa & 0 & 0.00 & 1 & 0.42 & 1 & 0.40 \\
\hline U. Madeira & 0 & 0.00 & 1 & 0.42 & 1 & 0.40 \\
\hline Total & 10 & 100.00 & 239 & 100.00 & 249 & 100.00 \\
\hline
\end{tabular}

Legend: ESENFC - Escola Superior de Enfermagem de Coimbra; IP - Instituto Politécnico; ISCTE-IUL - Instituto Universitário de Lisboa; RCAAP - Repositório Científico de Acesso Aberto de Portugal; U. - University.

In Portugal, a master's degree can be awarded for a 'scientific dissertation or project work that are original and especially made for this purpose, or a professional nature internship that is the final report object, in accordance with the intended specific objectives and under terms specified by the respective regulations ${ }^{\prime 25)}$. Thus it was found that $6.35 \%(n=16)$ of works corresponded to project works, and $23.41 \%(\mathrm{n}=59)$ corresponded to internship reports.

Regarding methodological approach, most representations are from quantitative approach works (31.35\%), followed by qualitative approach $(27.78 \%)$. Four studies did not identify the methodology used. One of the dissertations presented three different quantitative studies with different populations (Table 3).

Table 3 - Distribution of scientific production by methodological approach ( $\mathrm{N}$ and \%) - Portugal, 2000-2014.

\begin{tabular}{lrr}
\hline \multirow{2}{*}{ Methodological approach } & \multicolumn{2}{c}{ Total } \\
\cline { 2 - 3 } & $\mathbf{N}$ & \% \\
\hline Quantitative & 79 & 44.63 \\
Qualitative & 70 & 39.55 \\
Systematic review of literature & 9 & 5.08 \\
Methodological study & 6 & 3.39 \\
Mixed & 5 & 2.82 \\
Unknown & 4 & 2.26 \\
Delphi technique & 2 & 1.13 \\
Integrative review of literature & 1 & 0.57 \\
Historical study & 1 & 0.57 \\
\hline Total & $\mathbf{1 7 7}$ & $\mathbf{1 0 0 , 0 0}$ \\
\hline
\end{tabular}

Regarding the study areas, only academic works that included some kind of investigation were accounted for. The study area was classified independently by each of the researchers and subsequently discussed to reach a consensus. The results were highly heterogeneous (Table 4). The area of most interest was the family/informal caregiver (20.81\%), followed by symptomatic control (13.30\%). It was also found that the less studied areas were patients' comfort at the end of life and spirituality/hope (1.73\%).

Table 4 - Distribution of scientific production by field of study ( $\mathrm{N}$ and \%) - Portugal, 2000-2014.

\begin{tabular}{lcc}
\hline \multirow{2}{*}{ Field of study } & \multicolumn{2}{c}{ Total } \\
\cline { 2 - 3 } Family/informal caregiver & N & \% \\
Symptom control & 23 & 20,69 \\
Ethical issues & 21 & 13,22 \\
Organization of care & 17 & 9,07 \\
Patient's quality of life & 16 & 9,20 \\
Decision making & 14 & 8,05 \\
Nurses' experiences & 13 & 7,47 \\
Training in palliative care & 9 & 5,17 \\
Quality of care & 7 & 4,02 \\
Nursing diagnoses & 6 & 3,45 \\
Health professionals' burnout & 6 & 3,45 \\
Patient's comfort at the end of life & 3 & 1,72 \\
Spirituality/hope & 3 & 1,72 \\
\hline Total & $\mathbf{1 7 4}$ & $\mathbf{1 0 0 , 0 0}$ \\
\hline
\end{tabular}


In relation to the target population, the students/health professionals $(38.51 \%)$ predominated, followed by patients (25.86\%) and family/caregiver (18.39\%) (Table 5). It was not possible to identify the target population in $2.30 \%$ of works. Some studies showed a mixed population (6.90\%).

Table 5 - Distribution of scientific production by target population ( $\mathrm{N}$ and \%) - Portugal, 2000-2014.

\begin{tabular}{lrc}
\hline & \multicolumn{2}{c}{ Total } \\
\cline { 2 - 3 } Target population & $\mathbf{N}$ & $\mathbf{\%}$ \\
\hline Student/health professional & 67 & 38.51 \\
Patient & 45 & 25.86 \\
Family/caregiver & 32 & 18.39 \\
Scientific literature & 10 & 5.75 \\
Patient/caregiver/health professional & 5 & 2.87 \\
Unknown & 4 & 2.30 \\
Others & 4 & 2.30 \\
Patient/health professional & 3 & 1.72 \\
Caregiver/health professional & 2 & 1.15 \\
Patient/caregiver & 2 & 1.15 \\
\hline Total & $\mathbf{1 7 4}$ & $\mathbf{1 0 0 . 0 0}$ \\
\hline
\end{tabular}

\section{DISCUSSION}

In Portugal, the development of academic scientific production in the area of palliative care is in clear expansion. During the study period were found 249 academic studies done by nurses in this area, and 174 included the development of some kind of investigation. This also seems to be an international trend that began in the last quarter of last century due to several factors: changes in priorities resulting of rapid population aging, political concerns regarding health, and the public opinion perception that people in a terminal phase suffer from uncontrolled symptoms, which violates their right to human dignity ${ }^{(7)}$.

Nineteen out of the 31 surveyed repositories had published academic papers that met the inclusion criteria of the present study. This is a relevant fact, given that in Portugal there are only six masters courses designed specifically to palliative care. The issue of the end of life involves different realities and arouses the nurses' interest in general. Four out of the six master courses are limited to the major Portuguese cities of Porto, Lisbon and Coimbra, which may hinder access to this type of training.

The offer of postgraduate education (master and $\mathrm{PhD}$ ) in adjacent themes to palliative care is much greater and more equitable across the country. The number of master courses in nursing is close to 70 . In relation to doctorates, there are four programs in nursing sciences, two in bioethics and one in gerontology and geriatrics ${ }^{(12)}$. Note that in Portugal, the academic master's degrees in nursing exist since 1991, while doctorates in nursing exist since $2000^{(25)}$. These aspects justify a higher number of master dissertations and a lower number of doctoral theses included in the study. Furthermore, the numerus clausus of master's degrees is higher than those of doctorates. In Portugal, the master's degrees are more frequent than the doctorate degrees.

Among the 19 institutions that have published on this theme, the Universidade Católica presented the highest scientific production (21.29\%), possibly because it offers this type of training since 2008 in the cities of Porto and Lisbon. The year with highest production of theses and dissertations was 2012, followed by 2013. These data are justified by the opening of a master course in palliative care in 2009 (Universidade do Porto), and two others in 2011 (Instituto Politécnico de Viana do Castelo and Instituto Politécnico de Castelo Branco). At the Universidade de Coimbra, the master course was created in 2012, thus, in 2015 is expected further increase in the number of academic scientific production in this area ${ }^{(12)}$.

The most frequently used methodological approach was the quantitative, followed closely by the qualitative method. Most studies of quantitative approach are cross-sectional studies of small to medium size, and there was a small quantity of multicenter studies. Although quantitative methods allow a statistical analysis among variables and a possible generalization, qualitative methods focus more on patterns that give meaning to phenomena and contribute to understanding the experience as a whole ${ }^{(26)}$. Thus, there is a certain division of the two methodologies. On the one hand, there is need to quantify certain phenomena statistically because palliative care is a relatively new area in Portugal. On the other hand, it is necessary to understand the nonquantifiable aspects that allow a more humane understanding of the experience, which is possible only by using the qualitative methodology.

There are many study areas, but the family/informal caregivers stood out as the most studied area (20.81\%). The family and caregivers are important elements in the provision of quality care to patients with palliative care needs ${ }^{(27)}$. These results are in line with other studies performed in Portuga ${ }^{(8,19)}$. The studies of interdisciplinary nature were predominant, i.e., those contributing to palliative care knowledge as a whole, rather than specific studies in the field of palliative nursing, which may contribute to development of specific nursing knowledge in this area. Studies conducted in the scope of community, in populations suffering from non-oncological diseases and pediatric populations were scarce. In these areas of palliative care there are clear gaps in knowledge production, which could be explored in future research and are consistent with results of similar international studies ${ }^{(6,28)}$.

The most investigated target populations were students/health professionals (38.51\%), followed by patients (25.86\%). This data can be justified by the access to the target population and the difficulty of performing research in this area, coupled with the usual vulnerability of patients and families.

Thus, it is clear that higher education has a key role in the development of scientific knowledge in any area ${ }^{(29-30)}$. In the case of palliative care and nurses, this issue is even more important. The representativeness of postgraduate training 
in different educational institutions of the country can contribute to the scientific production increase in this specific area, but also contribute to disseminate this philosophy through the recognition of nurses as central elements in palliative care teams.

A limitation of this study is related to the choice of search terms, which may not have contemplated other studies in the area of palliative care that used different terminology. Another limitation was restricting the search for academic papers to electronic repositories, since there may be physical studies in the university libraries that were not included in this study.

\section{CONCLUSION}

The aim of this study was to identify the scientific production on palliative care of nurses in postgraduate studies in Portugal. In recent years, the growing interest of nurses in palliative care is a reality and seems to meet the health needs of an increasingly aging population.

The contribution of this study is the identification of the most investigated issues, methodologies and target populations by nurses in the area of palliative care, which could be significant in guiding the choice of future investigations. Since the descriptors and abstracts of dissertations and theses are central elements of the work, these sections should be elaborated with more rigor.

The growth of nurses' scientific production on palliative care is a reality. However, there is need for greater investment in quantity and quality, both in the offer of training and in scientific production in order to meet the needs and gaps felt by health professionals, patients and families, and with the objective of continuous improvement of care, by contributing with the maximization of well-being and quality of life in palliative care.

\section{RESUMO}

Objetivo: Identificar a produção científica académica sobre cuidados paliativos nos estudos de mestrados e doutoramentos efetuados por enfermeiros em Portugal. Método: Estudo descritivo e retrospetivo, do tipo bibliométrico, recorrendo aos resumos disponíveis nos repositórios das instituições de ensino superior no período 2000-2014. Resultados: Dos 1814 trabalhos identificados, 249 corresponderam aos critérios de inclusão (10 teses de doutoramento e 239 dissertações de mestrado). A abordagem metodológica mais representativa é a quantitativa (31,35\%), a área mais estudada foi a família/cuidador informal (20,69\%) e a população-alvo mais estudada foram os estudantes/profissionais de saúde (38,51\%). Conclusão: A produção científica académica nessa área tem vindo a crescer. Embora exista necessidade de investimento contínuo de forma a colmatar as lacunas identificadas.

\section{DESCRITORES}

Cuidados Paliativos; Enfermagem; Bibliometria; Portugal.

\section{RESUMEN}

Objetivo: Identificar la producción científica académica acerca de los cuidados paliativos en los estudios de maestrías y doctorados llevados a cabo por enfermeros en Portugal. Método: Estudio descriptivo y retrospectivo, del tipo bibliométrico, recurriendo a los resúmenes disponibles en los repositorios de las instituciones de enseñanza superior en el período 2000-2014. Resultados: De los 1814 trabajos identificados, 249 correspondieron a los criterios de inclusión (10 tesis de doctorado y 239 tesis de maestría). El abordaje metodológico más representativo es el cuantitativo (31,35\%), el área más estudiada fue la familia/cuidador informal (20,69\%) y la población meta más estudiada fueron los estudiantes/profesionales sanitarios (38,51\%). Conclusión: La producción científica académica en esa área está creciendo. Aunque exista necesidad de inversión continua de modo a rellenar los espacios identificados.

\section{DESCRIPTORES}

Cuidados Paliativos; Enfermería; Bibliometria; Portugal.

\section{REFERENCES}

1. World Health Organization (WHO). National Cancer Control Programmes: policies and managerial guidelines. Geneva: WHO; 2002.

2. Neto I, Marques AL, Gonçalves E, Salazar H, Capelas ML, Tavares M, et al. Palliative Care development is well under way in Portugal. Eur J Palliat Care. 2010;17(6):278-81.

3. Lisboa. Direção Geral da Saúde. Programa Nacional de Cuidados Paliativos. Lisboa; 2004.

4. Capelas ML. Cuidados paliativos: uma proposta para portugal. Cad Saúde. 2009;2(1): 51-7.

5. Associação Portuguesa de Cuidados Paliativos. Equipas de Cuidados Paliativos [Internet]. Lisboa; 2015 [citado 2015 mar. 30 ]. Disponível em: http://www.apcp.com.pt/cuidados-paliativos/equipas-de-cuidados-paliativos.html

6. Henoch I, Carlander I, Holm M, James I, Sarenmalm J, Hagelin C, et al. Palliative care research: a systematic review of foci, designs and methods of research conducted in Sweden between 2007 and 2012. Scand J Caring Sci. 2016;30(1):5-25.

7. George L. Research design in end-of-life research: state of art. Gerontologist. 2002; Suppl. III:S86-98.

8. Santos M, Capelas ML. Investigação em cuidados paliativos em Portugal. Cad Saúde. 2011;4(1):63-9.

9. Sigurdardottjr K, Haugen D, Rijt C, Sjøgren P, Harding R, Higginson I, et al. Clinical priorities, barriers and solutions in end-of-life cancer care research across Europe. Report from a Workshop. Eur J Cancer. 2010;46(18):1815-22.

10. Lynch T, Clark D, Centeno C, Rocafort J, Lima L, Filbet M, et al. Barriers to the development of palliative care in Western Europe. Palliat Med. 2010;24(8):812-9. 
11. World Health Organization. Worldwide Palliative Care Alliance. Global atlas of palliative care at the end of life. Geneva: WHO, 2014.

12. Portugal. Agência de Avaliação e Acreditação do Ensino Superior - A3ES. Acreditação de Ciclos de Estudos [Internet]. Lisboa; 2015 [citado 2015 abr. 10]. Disponível em: http://www.a3es.pt/pt/acreditacao-e-auditoria/resultados-dos-processos-de-acreditacao/acreditacao-deciclos-de-estudos

13. Radbruch L, Payne S, Bercovitch M, Caraceni A, Vlieger T, Firth P, et al. White paper on standards and norms for hospice and palliative care in Europe: part 1. Eur J Palliat Care. 2009;16(6):278-89.

14. Cummings I. The interdisciplinary team. In: Hanks G, Cherny N, Christakis N, Fallon M, Kaasa S, Portenoy R, editors. Oxford textbook of palliative medicine. Oxford: Oxford University Press; 1998. p. 19-30.

15. City K, Labyak M. Hospice palliative care for the 21st century: a model for quality end-of-life care. In: Ferrell B, Coyle N, editors. Oxford textbook of palliative nursing. Oxford: Oxford University Press; 2010. p. 13-52.

16. Reed S. A unitary-caring conceptual model for advance practice nursing in palliative care. Holist Nurs Pract. 2010;24(1):23-34

17. Mok E, Chiu P. Nurse-patient relationships in palliative care. J Adv Nurs. 2004;48(5): 475-83.

18. Lynch M, Dahlin C, Coakley E. Palliative care nursing: defining the discipline? J Hosp Palliat Nurs. 2011;13(2):106-11.

19. Pinto S, Martins J, Barbieri-Figueiredo M. Investigación en cuidados paliativos y enfermería. Index Enferm. 2014;23(3):178-82.

20. Ferrari A. Metodologia da pesquisa científica. São Paulo: Mcgraw-Hill; 1992.

21. Silva AM, Martini JG, Becker SG. A teoria das representações sociais nas dissertações e teses de enfermagem: um perfil bibliométrico. Texto Contexto Enferm. 2011;20(2): 294-300.

22. Reibnitz KS, Prado ML, Lima MM, Kloh D. Pesquisa convergente-assistencial: estudo bibliométrico de dissertações e teses. Texto Contexto Enferm. 2012;21(3):702-7.

23. Hayashi MC, Hayashi CR, Silva MR, Lima MY. Um estudo bibliométrico da produção científica sobre a educação jesuítica no Brasil colonial. Biblios [Internet]. 2007 [citado 2015 abr. 10];8(27). Disponible en: http://www.redalyc.org/artículo.oa?id=16102702

24. Ranking Web of Repositories - Portugal [Internet]. Madrid: Cybermetrics Lab; 2015 [citedo 2015 Febr 24]. Available from: http://repositories. webometrics.info/en/Europe/Portugal

25. Portugal. Decreto-Lei 115/2013, de 7 de agosto. Regulamenta a avaliação da aplicação dos diplomas estruturantes do ensino superior. Diário da República, Lisboa, 7 Ago. 2013. Série I, No 151, p. 4749.

26. Baggio MA, Rodrigues, MA, Erdmann AL, Barbieri-Figueiredo MC, Vieira MM. Produçoes de teses e dissertações da enfermagem em Portugal de 2000-2010: estudo bibliométrico. Texto Contexto Enferm. 2014;23(2):250-60.

27. Polit D, Beck C. Nursing research: generating and assessing evidence for nursing practice. 9th ed. London: Lippincott Williams \& Wilkins; 2012.

28. Mcllfatrick S, Murphy T. Palliative care research on the island of ireland over the last decade: a systematic review and thematic analysis of peer reviewed publications. BMC Palliat Care. 2013;12(1):33.

29. Hudson P, Aranda S, Kristjanson L. Meeting the supportive needs of family caregivers in palliative care: challenges for health professionals. J Palliat Med. 2004;7(1):19-25.

30. Santos MS, Sousa MF, Queiroz AM, Sousa FJ, Silva LL. Saúde Mental e psiquiatrica nas dissertações e teses em Enfermagem: um estudo bibliométrico. Rev Bras Pesqui Saúde. 2013;15(3):72-8. 